\title{
Does investment in human resource development affect financial performance? Empirical evidence from the banking sector of Bangladesh
}

\author{
Mohammad Zahid Hossain Bhuiyan, \\ Md. Mahi Uddin, Afzal Ahmad, \\ and Nazamul Hoque \\ Department of Business Administration \\ International Islamic University Chittagong (IIUC), Bangladesh
}

\begin{abstract}
The study aims at examining the impact of investment in human resource development (HRD) on the financial performance of the banking sector of Bangladesh. Using the economic data as well as survey data collected from purposively selected 120 bank executives of 20 private commercial banks of Bangladesh. The study through regression models finds that there is a significant positive correlations between HRD investment (in salaries and allowances, provident fund and gratuity, bonus and incentives, staff welfare and training, workshop, and seminar) and financial performance of the sample banks. Though, training is one of the important HRD indicators, the lowest investment was made in this sector by the sample banks. The findings of the study may be useful for bankers, policymakers, HR professionals, and the stakeholders of all types of organizations regardless of the geographical boundary. Finally, further investigations on manufacturing and other service sectors through case study, focus groups, and longitudinal study are also suggested.
\end{abstract}

Keywords Financial performance, Human resource development, Productivity, Profitability

Paper type Research paper

\section{Introduction}

Human resource development is the key to human resource management (HRM). There is no value of raw human capital unless and until they are capable enough to manage the organization in line with its mission, vision, and goals. Also, human resource development (HRD) is that intervention of HRM by which raw human capital is transformed into the capable and skilled human

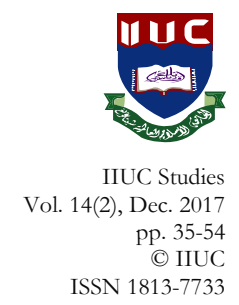


resources. Therefore, HRD is a continuous process mainly designed to enhance employee's satisfaction, performance and thereby improving organizational effectiveness (Becker \& Gerhart, 1996). It is a planned intervention and initiative to ease employee's learning on job-related competencies including attitude, behavior, and knowledge to improve the performance of the employees (Baniya, 2004).

On the other hand, HRD investment is the total monetary value of allocated and distributed for enhancing their knowledge, skills, and abilities (KSA) necessary for running the organization efficiently and effectively. Gidado, Kusairi, \& Muhamad (2014) observed that investment in the HRD is a must for improving the efficiency of human capital and thereby enhancing the productivity and performance of an organization. Human capital theory (Sweetland, 1996) in this regard argues that investment in people leads to economic benefits to the organization.

Nowadays, the impact of HRD investments on financial performances of the organizations has been catching the leading research issue in the field of human resource management (Huselid, 1995; Liao, 2005; Singh, 2004) because of workforce diversity (Becker \& Gerhart, 1996), rapid change of the demand of the customer and advancement of information technology (Gidado, Kusairi, \& Muhamad, 2014)) in an attempt to achieve sustainable competitive advantage (Becker \& Gerhart, 1996; Lado \& Wilson, 1994; Wright \& McMahan, 1992). Since human resources are the potential sources of sustainable competitive advantage, managing them well, in turn, drive competitiveness (Cappelli \& Anne, 1996; Ivancevich, 2003). This, in principle, facilitates the organizations to desirable financial performance (Guest, 1997, 2011; Huselid, 1993).

In the early days, researchers were involved in exploring the effect of investment in HRD on employee vice-a-versa organizational performance (Arthur, 1994). Currently, it has been identified that the practices of HRD speculation has a considerable impact on the financial performance of the organizations (Arthur, 1994; Harel \& Tzafrir, 2004; Qureshi, Akbar, Khan, Sheikh, \& Hijazi, 2010; Randall \& Ferry, 1992) specially in service organizations such as banking industries which extensively depends on high level of professionalism (Gidado, Kusairi, \& Muhamad, 2014). Following the recent financial crisis, organizations including the banking sector all over the world are facing hardship in mobilizing their resources. Thus, contemporary challenges like cross-country diversification (Becker \& Gerhart, 1996), adverse fluctuation rate in currency, deregulation (Huselid, 1995) and constant nuclear threats from the western makes the organizations more dynamic and competitive (Lepak \& Snell, 1999, 2002). It is now recognized that all resources minus human resources equal to zero. Therefore, long-term 
growth in an economy with efficiency and effectiveness depends on productive investment in HRD (Olayemi, 2012: 298).

Likewise, for the last few decades, Bangladesh is emphasizing on banking growth. For the sustainable economic progress of the country, different banks are performing a paramount role. However, a good number of banks are now suffering from a variety of structural and institutional weaknesses, which has constrained their capacity to take full advantage of the rapidly advancing process of global activities and HRM practices. This circumstance has led to increased interest in the impact of investment in HRD on the financial performance of the banking industries in Bangladesh.

\section{Objectives and hypotheses}

The study aims at investigating the impact of investments in human resource development on the financial performance of private commercial banks (PCBs) operating in Bangladesh. The study highlights the following specific objectives:

a. To explore the indicators of HRD on organizational financial performance

b. To examine the impact of financial performances based on return on investment (ROI) and deposit per employee (DPE).

c. To measure the effect of investment in HRD on bank productivity and profitability.

Hypotheses of the study

Following two hypotheses have been developed from the above objectives:

Hypothesis 1: Investment in HRD has a significant association with productivity and profitability.

Hypothesis 2: Investment in $\mathrm{HRD}$ has a significant impact on productivity and profitability.

\section{Review of literature}

\subsection{Human resource development and its importance}

Human resource development (HRD) in an organization is a planned effort to facilitate employee's learning of job-related behavior, skills, knowledge, and attitude to improve the performance of the employee (Baniya, 2004). According to Swanson (1995), "HRD is a process of developing and unleashing human expertise through organization development and personnel training to improve organizational 
performance". It is the process of gaining organizational objective by reducing employee turnover (Gidado, Kusairi, \& Muhamad, 2014). Therefore, it is an ongoing process mainly designed to enhance employee's performance and satisfaction thereby improving organizational effectiveness (Stavrou-Costea, 2005). On the other hand, investment in HRD is the total value of human resources in the business for sustainable growth, (Bohlander \& Snell, 2004).

In a study conducted by Qureshi, Akbar, Khan, Sheikh, \& Hijazi (2010) confirmed that organizational performance is largely derived from its human resources. HRM practices help organizations to improve their business performance (Delaney \& Huselid, 1996; Lee \& Lee, 2007; Zaini, Nilufar, \& Syed, 2009). Various studies (Becker \& Huselid, 1992; Benjamin, 2011; Guest, 1997, 2011; Huselid, 1995; Lepak \& Snell, 1999; Swanson, 1995; Wan, Ong, \& Kok, 2002) demonstrated a positive association between HRD investment and organizational performance. Similarly, in the context of Bangladesh, it is found a significant association between reduction of employee turnover and organizational commitment with the effective practices of HR activities (Billah \& Islam, 2009; Billah, Prince, \& Islam, 2009).

\subsection{Indicators of investment in HRD}

Financial performance of the organizations depends on investment in HRD. Earlier works of literature recognized a good number of indicators of investment in HRD. For example, salaries enhancement (Becker \& Huselid, 1992; Bradley, Petrescu, \& Simmons, 2004; Huselid, 1995), bonuses and incentives (Al-Ghazawi, 2012; Bartell, 2004; Huselid, 1995; Jones \& Wright; 1992; Lee \& Lee, 2007), daily income and expenditures (Khan \& Ali, 2014), capacity against natural calamities (Khan \& Ali, 2015) and rewards (Bradley, Petrescu, \& Simmons, 2004) were identified as the major dimensions in HRD investment.

Similarly, employee security (Lee \& Lee, 2007), performance appraisal (Borman, 1991; Jones \& Wright, 1992), linking of performance appraisal with compensation (Gerhart \& Milkovich, 1992; Huselid, 1995; Lee \& Lee, 2007), HR planning (Lee \& Lee, 2007), formal recruitment \& selection (AlGhazawi, 2012; Huselid, 1995; Jones \& Wright, 1992; Rawashdeh \& AlAdwan, 2012; Terpstra \& Rozell, 1993) and training \& development (AlGhazawi, 2012; Armenta, 2007; Aswathappa, 2008; Ebiringa \& Okorafor, 2010; Hoque, 1994; Huselid, 1995; Jones \& Wright, 1992; Rusell, Terborg, \& Powers, 1985; Thang \& Buyens, 2008; Tzafrir, 2006) considered as the most important indicators of the investment in HRD. 


\subsection{Indicators of financial performance about $H R D$}

Concerned authors in their study used different measures to find out the performance of the organization. Productivity and profitability (Bhuiyan, Islam, \& Rahman, 2013; Huselid, 1995) are commonly used to know the financial performances on the bank. A variety of measures like Return on Asset (ROA), (Bhuiyan et al., 2013; Gidado, Kusairi, \& Muhamad, 2014; Hsu, Lin, Lawler, \& Wu, 2007; Selvarajan, Ramamoorthy, Flood, Guthrie, MacCurtain, \& Liu, 2007), Return on Investment (ROI), (Bhuiyan et al., 2013; Grossman, 2000), earnings per share (EPS) (Bhuiyan et al., 2013; Gidado et al., 2014), net income after tax (NIAT) (Bhuiyan et al., 2013; Grossman, 2000), return on equity (ROE) (Bhuiyan et al., 2013; Gidado et al., 2014), deposit per employee (DPE) (Bhuiyan et al., 2013) etc. are used to identify the performances of the organizations.

Thus, the above review of the literature shows that there have been several studies around the world focusing on HR practices and organizational performance. However, very few numbers of the studies have been conducted on the impact of HRD practices on organizational financial performance especially in the context of banking industries in Bangladesh. This study has been undertaken to fill this obvious research gap.

\section{Methodology and Research Design}

The methodology in this study has been discussed under the main points given below:

\subsection{Sample selection}

In the study, 20 private commercial banks (PCBs) out of 57 scheduled banks operating in Bangladesh were selected purposely due to the easy access to the requisite data. The list of the scheduled banks is as follows:

Table 1: List of the scheduled banks in Bangladesh

\begin{tabular}{llr}
\hline SL. & Nature of Banks & Total No. of Banks \\
\hline 1. & State Owned Commercial Banks (SOCBs) & 06 \\
2. & Conventional Private Commercial Banks (PCBs) & 32 \\
3. & Islamic Shariah based PCBs & 08 \\
4. & Specialized Banks & 02 \\
5. & Foreign Commercial Banks (FCBs) & 09 \\
& Total: & 57 \\
\hline
\end{tabular}

Source: Bangladesh Bank website: www.bb.org.bd

The selected banks are the local banks, and the names of the banks are enclosed in Appendix 1. An opinion survey consisting of a total number of 120 respondents was conducted for collecting primary data, of which, two executives in the rank and status of manager (in-charge) of 
Human Resource Development and Accountant (in-charge) of profitability of the banks were taken into consideration. Again, four HR executives from each of the sample banks were selected. These respondents were also purposively chosen to keep in mind the main objective of the study.

\subsection{Data collection \\ Secondary data}

The study is mainly based on secondary data which have been collected through total assets, total deposits, total investments, total number of employees, return on investment (ROI) and deposit per employee (DPE) and so on of the sample banks. These data were collected by the researchers from the annual accounts statements, annual reports, and websites of the banks. Again, the main measures of profitability of the banks have been ROI, ROCE, ROTA, and EPS, etc. But in this study, only ROI and DPE have been used to examine the impact of investment in HRD on financial performances of the selected banks.

\section{Primary Data}

Although the study is mainly based on secondary data, some primary data for the identification of the indicators of investments in HRD of the banks were also used. A semi-structured questionnaire was used by the researchers for collecting primary data from the respondents by direct interview method. Following groups of indicators of HRD have been identified during interviews which were validated from the existing pieces of literature on the subject:

a. Salaries and allowances

b. Bonus and incentives

c. Provident fund and gratuity etc.

d. Training, recruitment, workshop, and seminars, etc. and

e. Staff welfare

\subsection{Study period}

A period of five financial years ranging from 2007 to 2011 was taken into consideration for the empirical analysis of the study. The secondary data of these fiscal years were collected easily because of availability in the bank websites. 


\section{HRD investment on financial performance 41}

\subsection{Methods of data analysis}

The primary data used in the study were few limiting to the opinions of the respondents as to the indicators of investment in HRD. Therefore, these data were processed and analyzed manually. Using the SPSS program, the secondary data were processed and analyzed. The Pearson correlation technique and multiple correlations and regression model have been used for the study to show the relationship between the dependent variables and independent variables, the association of strength between these variables and to show the extent of the influence of the independent variables on the dependent variables. To test the hypothesis of the study, t-test, F-test and ANOVA have been applied in the study. For the study purpose, Return on Investment (ROI) and Deposit per Employee (DPE) have been taken as the dependent variables, while the independent variables are salaries and allowances, bonus and others, provident fund and gratuity, training, recruitment, workshop and seminars, and staff welfare.

\section{Analysis of findings}

\subsection{Analysis of investment in HRD indicators}

After studying the annual reports of the sample banks during the study period, the following Table 2 has been prepared.

Table 2 presents the average position of investment in HRD regarding significant the heads and the total amount in investment in the selected banks from 2007 to 2011. The said table reveals that concerning the total investment in HRD, IBBL occupies the 1st rank followed by UCBL, BBL, PuBL, CBL, PBL, ABBL, DBBL EBL IFIC, BAL, NCCBL, DBL, SBL, SJIBL, SIBL, TBL, MTBL, FSIBL, and ICB. The table also portrays that of all the five heads of investment, salaries \& allowances occupy 1 st rank with $67.74 \%$ of the total investment, provident fund and gratuity with $14.33 \%$ of the total investment, bonus and incentives with $13.5 \%$ of the total investment, staff welfare with $3.66 \%$ of the total investment and lastly, training, workshop etc. with $0.77 \%$ of total investment only. These positions are determined regarding the average investment. From the figures shown in Table I, it can be said that investment in salaries and allowance ranges between $37.47 \%$ and $78.90 \%$; investment in bonus and others range between $6.50 \%$ and $21.53 \%$; investment in provident fund and gratuity ranges between $3.41 \%$ and $48.62 \%$; investment in training, recruitment, workshop, etc. ranges between $0.05 \%$ and $3.69 \%$ and investment in staff welfare ranges between $0.78 \%$ and $9.05 \%$ among the sample banks. This analysis indicates that 


\section{IIUC Studies, 14(2)}

lowest investment has been made in training, recruitment, workshop, etc. which implies that the selected banks do not attach due importance to the training and development.

Table 2: Average position of investment in HRD during 2007-2011

\begin{tabular}{|c|c|c|c|c|c|c|c|c|}
\hline SL. & Bank & $\begin{array}{l}\text { Salaries and } \\
\text { allowances }\end{array}$ & $\begin{array}{l}\text { Bonus and } \\
\text { incentives }\end{array}$ & $\begin{array}{l}\text { Provident } \\
\text { fund and } \\
\text { gratuity }\end{array}$ & $\begin{array}{c}\text { Training, } \\
\text { workshop, } \\
\text { seminar, } \\
\text { recruitment }\end{array}$ & Staff welfare & $\begin{array}{c}\text { Total } \\
\text { investment }\end{array}$ & Ranl \\
\hline 1 & $\mathrm{ABBL}$ & $\begin{array}{c}5130.45 \\
(77.19 \%)\end{array}$ & $\begin{array}{c}764.07 \\
(11.50 \%)\end{array}$ & $\begin{array}{c}462.58 \\
(6.96 \%)\end{array}$ & $\begin{array}{c}47.24 \\
(0.71 \%)\end{array}$ & $0.71(3.64 \%)$ & $6646.23(100 \%)$ & \\
\hline 2 & BAL & $\begin{array}{c}2476.72 \\
(67.64 \%)\end{array}$ & $\begin{array}{c}781.44 \\
(21.34 \%)\end{array}$ & $\begin{array}{c}202.17 \\
(5.52 \%)\end{array}$ & $\begin{array}{c}56.59 \\
(1.55 \%)\end{array}$ & $1.55(3.96 \%)$ & $3661.88(100 \%)$ & 11 \\
\hline 3 & BBL & $\begin{array}{c}7449.62 \\
(77.05 \%)\end{array}$ & $\begin{array}{c}1244.14 \\
(12.87 \%)\end{array}$ & $\begin{array}{c}827.74 \\
(8.56 \%)\end{array}$ & $\begin{array}{c}71.36 \\
(0.74 \%)\end{array}$ & $0.74(0.78 \%)$ & $9668.16(100 \%)$ & \\
\hline 4 & $\mathrm{CBL}$ & $\begin{array}{c}5579.77 \\
(70.26 \%)\end{array}$ & $\begin{array}{c}700.75 \\
(8.82 \%)\end{array}$ & $\begin{array}{c}1241.2 \\
(15.63 \%)\end{array}$ & $\begin{array}{c}144.39 \\
(1.82 \%)\end{array}$ & $1.82(3.47 \%)$ & $7941.36(100 \%)$ & \\
\hline 5 & DBL & $\begin{array}{c}2467.98 \\
(68.99 \%)\end{array}$ & $\begin{array}{c}554.1 \\
(15.49 \%)\end{array}$ & $\begin{array}{c}389.44 \\
(10.89 \%)\end{array}$ & $\begin{array}{c}20.97 \\
(0.59 \%)\end{array}$ & $0.59(4.05 \%)$ & $3577.45(100 \%)$ & 13 \\
\hline 6 & DBBL & $\begin{array}{c}3399.05 \\
(68.15 \%)\end{array}$ & $\begin{array}{c}898.75 \\
(18.02 \%)\end{array}$ & $424.8(8.52 \%)$ & $38.8(0.78 \%)$ & $0.78(4.53 \%)$ & $4987.25(100 \%)$ & . \\
\hline 7 & EBL & $\begin{array}{c}3616.47 \\
(75.36 \%)\end{array}$ & $\begin{array}{c}631.94 \\
(13.17 \%)\end{array}$ & $\begin{array}{c}308.27 \\
(6.42 \%)\end{array}$ & $\begin{array}{c}65.28 \\
(1.36 \%)\end{array}$ & $1.36(3.69 \%)$ & $4798.86(100 \%)$ & . \\
\hline 8 & FSIBL & $\begin{array}{c}819.47 \\
(61.76 \%)\end{array}$ & $\begin{array}{c}221.97 \\
(16.73 \%)\end{array}$ & $\begin{array}{c}116.33 \\
(8.77 \%)\end{array}$ & $49(3.69 \%)$ & $3.69(9.05 \%)$ & $1326.87(100 \%)$ & 19 \\
\hline 9 & IBBL & $\begin{array}{l}13729.88 \\
(76.66 \%)\end{array}$ & $\begin{array}{l}1695.05 \\
(9.46 \%)\end{array}$ & $\begin{array}{l}1525.54 \\
(8.52 \%)\end{array}$ & $\begin{array}{c}150.04 \\
(0.84 \%)\end{array}$ & $0.84(4.52 \%)$ & $\begin{array}{c}17909.95 \\
(100 \%)\end{array}$ & \\
\hline 10 & ICB & $\begin{array}{c}874.68 \\
(78.90 \%)\end{array}$ & $\begin{array}{c}79.06 \\
(7.13 \%)\end{array}$ & $94.38(8.51 \%)$ & $\begin{array}{c}10.45 \\
(0.94 \%)\end{array}$ & $0.94(4.51 \%)$ & $1108.56(100 \%)$ & 20 \\
\hline 11 & IFIC & $\begin{array}{c}2459.03 \\
(55.85 \%)\end{array}$ & $\begin{array}{c}924.85 \\
(21.01 \%)\end{array}$ & $\begin{array}{c}833.49 \\
(18.93 \%)\end{array}$ & $2.26(0.05 \%)$ & $0.05(4.16 \%)$ & $4402.78(100 \%)$ & 10 \\
\hline 12 & MTBL & $\begin{array}{c}1621.93 \\
(69.47 \%)\end{array}$ & $\begin{array}{c}371.56 \\
(15.92 \%)\end{array}$ & $210(8.99 \%)$ & $\begin{array}{c}24.81 \\
(1.06 \%)\end{array}$ & $1.06(4.56 \%)$ & $2334.65(100 \%)$ & 18 \\
\hline 13 & $\begin{array}{l}\mathrm{NCCB} \\
\mathrm{L}\end{array}$ & $\begin{array}{c}2660.73 \\
(73.86 \%)\end{array}$ & $\begin{array}{c}631.49 \\
(17.53 \%)\end{array}$ & $\begin{array}{c}138.53 \\
(3.85 \%)\end{array}$ & $7.81(0.22 \%)$ & $0.22(4.55 \%)$ & $3602.35(100 \%)$ & 12 \\
\hline 14 & PBL & $\begin{array}{c}4798.36 \\
(64.41 \%)\end{array}$ & $\begin{array}{c}1603.46 \\
(21.53 \%)\end{array}$ & $\begin{array}{c}623.42 \\
(8.37 \%)\end{array}$ & $\begin{array}{c}63.94 \\
(0.86 \%)\end{array}$ & $0.86(4.83 \%)$ & $7449.20(100 \%)$ & 0 \\
\hline 15 & PuBL & $\begin{array}{c}6546.94 \\
(68.17 \%)\end{array}$ & $\begin{array}{c}624.17 \\
(6.50 \%)\end{array}$ & $\begin{array}{c}2218.23 \\
(23.10 \%)\end{array}$ & $23.7(0.25 \%)$ & $0.25(1.99 \%)$ & $9604.25(100 \%)$ & 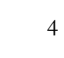 \\
\hline 16 & SBL & $\begin{array}{c}2261.34 \\
(67.75 \%)\end{array}$ & $\begin{array}{c}602.47 \\
(18.05 \%)\end{array}$ & $\begin{array}{c}284.57 \\
(8.53 \%)\end{array}$ & $9.65(0.29 \%)$ & $0.29(5.38 \%)$ & $3337.69(100 \%)$ & 14 \\
\hline 17 & SJIBL & $\begin{array}{c}1854.47 \\
(64.19 \%)\end{array}$ & $\begin{array}{c}615.88 \\
(21.32 \%)\end{array}$ & $\begin{array}{c}262.51 \\
(9.09 \%)\end{array}$ & $7.07(0.24 \%)$ & $0.24(5.16 \%)$ & $2888.92(100 \%)$ & 15 \\
\hline 18 & SIBL & $\begin{array}{c}2065.51 \\
(79.05 \%)\end{array}$ & $\begin{array}{c}363.88 \\
(13.93 \%)\end{array}$ & $89.16(3.41 \%)$ & $5.48(0.21 \%)$ & $0.21(3.40 \%)$ & $2612.77(100 \%)$ & 16 \\
\hline 19 & TBL & $\begin{array}{c}1602.16 \\
(62.93 \%)\end{array}$ & $\begin{array}{c}524.14 \\
(20.59 \%)\end{array}$ & $\begin{array}{c}272.53 \\
(10.70 \%)\end{array}$ & $\begin{array}{c}16.17 \\
(0.64 \%)\end{array}$ & $0.64(5.14 \%)$ & $2545.85(100 \%)$ & 17 \\
\hline 20 & UCBL & $\begin{array}{c}4216.06 \\
(37.47 \%)\end{array}$ & $\begin{array}{c}1254.49 \\
(11.15 \%)\end{array}$ & $\begin{array}{c}5470.55 \\
(48.62 \%)\end{array}$ & $40.2(0.36 \%)$ & $0.36(2.40 \%)$ & $\begin{array}{c}11250.84 \\
(100 \%)\end{array}$ & \\
\hline $\begin{array}{l}\text { San } \\
\text { Ave }\end{array}$ & $\begin{array}{l}\text { ple } \\
\text { rage }\end{array}$ & $\begin{array}{c}3781.53 \\
(67.74 \%)\end{array}$ & $\begin{array}{c}754.38 \\
(13.51 \%)\end{array}$ & $\begin{array}{c}799.77 \\
(14.33 \%)\end{array}$ & $\begin{array}{c}42.76 \\
(0.77 \%)\end{array}$ & $204.35(3.66 \%)$ & $5582.79(100 \%)$ & \\
\hline Rar & & 1 & 3 & 2 & 5 & 4 & & \\
\hline \multirow{2}{*}{\multicolumn{2}{|c|}{ Range }} & Max: $78.90 \%$ & Max: $21.53 \%$ & Max: $48.62 \%$ & Max: $3.69 \%$ & Max: $9.05 \%$ & & \\
\hline & & Min: $37.47 \%$ & Min: $6.50 \%$ & Min: $3.41 \%$ & Min: $0.05 \%$ & Min: $0.78 \%$ & & \\
\hline
\end{tabular}

Note: Figures in the parentheses indicate percentage position

Source: Based on data presented in Annual Reports of the selected banks 


\subsection{Position of financial performances based on ROI \& DPE}

The financial performance of any organization whether manufacturing, banking or any other service industries are measured in various ways namely productivity criteria, profitability criteria, and value-added criteria. In this study, only productivity and profitability measures have been used.

\section{Position of financial performances based on ROI}

There are various measures of profitability namely gross return on investment, return on equity, earning per share, return on profit margin, return on capital employed, net profit margin and so on. Of all these measures, ROI is the most common and necessary measure. The following Table 3 shows the position of ROI during 2007-2011.

Table 3: Position of financial performances based on ROI

\begin{tabular}{|c|c|c|c|c|c|c|c|c|}
\hline SL. & Bank & 2007 & 2008 & 2009 & 2010 & 2011 & Average & Rank \\
\hline 1 & ABBL & 23 & 23.89 & 21.06 & 32.72 & 14.62 & 23.06 & 1 \\
\hline 2 & BAL & 11.09 & 13.88 & 18.61 & 15.79 & 13.98 & 14.67 & 4 \\
\hline 3 & BBL & 11.64 & 12.61 & 12.3 & 9 & 12.41 & 11.59 & 11 \\
\hline 4 & $\mathrm{CBL}$ & 12 & 14 & 13 & 19 & 9 & 13.40 & 5 \\
\hline 5 & DBL & 8.68 & 9.18 & 11.58 & 14.53 & 22.76 & 13.35 & 6 \\
\hline 6 & DBBL & 9.69 & 9.48 & 14.64 & 12.17 & 14.11 & 12.02 & 10 \\
\hline 7 & EBL & 11.42 & 12.89 & 13.79 & 14.34 & 11.93 & 12.87 & 9 \\
\hline 8 & FSIBL & 7 & 15 & 3 & 9 & 2 & 7.20 & 19 \\
\hline 9 & IBBL & 10 & 11 & 10 & 10 & 11 & 10.40 & 13 \\
\hline 10 & ICB & 0 & 15 & 8 & 3 & 2 & 5.60 & 20 \\
\hline 11 & IFIC & 14 & 14 & 14 & 17 & 17 & 15.20 & 3 \\
\hline 12 & MTBL & 4.1 & 8.11 & 8.99 & 11.13 & 7.7 & 8.01 & 17 \\
\hline 13 & NCCBL & 8.3 & 9.77 & 11.08 & 14.59 & 11.26 & 11.00 & 12 \\
\hline 14 & PBL & 12.6 & 9.74 & 15.67 & 13.02 & 15.09 & 13.22 & 7 \\
\hline 15 & PuBL & 7 & 5 & 9 & 13 & 7 & 8.20 & 16 \\
\hline 16 & SBL & 20 & 13 & 2 & 2 & 2 & 7.80 & 18 \\
\hline 17 & SJIBL & 11 & 17 & 12 & 39 & 3 & 16.40 & 2 \\
\hline 18 & SIBL & 18 & 13 & 4 & 11 & 3 & 9.80 & 15 \\
\hline 19 & TBL & 10 & 13 & 14 & 22 & 7 & 13.20 & 8 \\
\hline 20 & UCBL & 8 & 9 & 10 & 13 & 10 & 10.00 & 14 \\
\hline
\end{tabular}

Source: Annual reports of the sample banks

Table 3, it is revealed that the average ROI during the study period, the majority of the banks has been satisfactory, since their ROI has exceeded the standard norm of 12 percent as recognized by some authors, 
for example, Weston and Brigham (1969). These banks are ABBL, BAL, CBL, DBL, DBBL, EBL, IFIC, PBL, SJIBL, and TBL. The average ROI of the remaining banks has not been satisfactory since their ROI has been below the standard norm of 12 percent. Considering the average ROI of the banks, it can be said that ABBL occupies the 1st rank with an average ROI of $23.06 \%$ followed by SJIBL with an average ROI of $16.40 \%$, IFIC with average ROI of $15.20 \%$, BAL with average ROI of $14.67 \%$, CBL with average ROI of $13.40 \%$, DBL with average ROI of $13.35 \%$, PBL with average ROI of $13.22 \%$, TBL with average ROI of $13.20 \%$, EBL with average ROI of $12.87 \%$, DBBL with average ROI of $12.02 \%$ and so on. Therefore, it can be concluded that the ROI of these ten banks have been satisfactory during the period 2007 to 2011.

Position of financial performances based on DPE

There are various productivity measures such as total deposits per employee (DPE), total loans and advances per employee, loans, and advances and investment to deposit, total business (total income) per employee, total investment per employee, total equity capital per employee, earning assets per employee, total expenditure per employee. Of all these measures, only DPE is related to the study because investment in HRD tends to increase the deposit of the banks. Therefore, the following Table 4 shows the position of DPE of the selected banks during 2007-2011.

It can be revealed from Table 4 that the average DPE of the selected banks during 2007-2011 has ranged from 11.54 to 62.99 times. Considering the average DPE, it can also be said that the majority of the banks have satisfactory DPE with more than 30 times of average DPE. The table also reveals that in terms of average DPE during the period, DBL occupies the 1 st rank with average DPE of 62.05 times followed by SBL with average DPE of 62.05 times, PBL with average DPE of 55.80 times, EBL with average DPE of 54.90 times, BAL with average DPE of 49.60 times, MTBL with average DPE of 46.11 times, ABBL with average DPE of 42.84 times, SJIBL with average DPE of 40.01 times, DBBL with average DPE of 38.28 times, NCCBL with average DPE of 37.05 times \& so on. On the other hand, the average DPE of BBL, CBL, FSIBL, IBBL, ICB, IFIC, PuBL has been below 30 times; hence these banks have unsatisfactory DPE during the period. Therefore, it can be concluded that the productivity regarding DPE of these ten banks have been highly satisfactory during 2007-2011 since average DPE of these banks has been more than 37.05 times. 
HRD investment on financial performance 45

Table 4: Position of financial performances based on deposit per employee (DPE)

\begin{tabular}{llccccccr}
\hline SL. & Bank & 2007 & 2008 & 2009 & 2010 & 2011 & Average & Rank \\
\hline 1 & ABBL & 30.94 & 38 & 42.57 & 47.66 & 55.03 & 42.84 & 7 \\
2 & BAL & 4.7 & 52.91 & 53.18 & 67.58 & 69.63 & 49.60 & 5 \\
3 & BBL & 8.44 & 9.57 & 12.61 & 12.25 & 14.81 & 11.54 & 19 \\
4 & CBL & 20.36 & 21.51 & 25.74 & 25.11 & 33.91 & 25.33 & 14 \\
5 & DBL & 57.94 & 63.46 & 65.93 & 61.08 & 66.54 & 62.99 & 1 \\
6 & DBBL & 53.37 & 41.97 & 37.98 & 30.13 & 27.94 & 38.28 & 9 \\
7 & EBL & 43.61 & 54.48 & 56.22 & 57.99 & 62.22 & 54.90 & 4 \\
8 & FSIBL & 29.49 & 19.6 & 18.3 & 20.02 & 19.85 & 21.45 & 17.5 \\
9 & IBBL & 20.58 & 10.68 & 25.48 & 28.21 & 28.75 & 22.74 & 15 \\
10 & ICB & 29.49 & 19.6 & 18.3 & 20.02 & 19.85 & 21.45 & 17.5 \\
11 & IFIC & 14.97 & 17.11 & 22.79 & 23.61 & 29.63 & 21.62 & 16 \\
12 & MTBL & 42.87 & 45.76 & 50.36 & 43.02 & 48.54 & 46.11 & 6 \\
13 & NCCBL & 28.38 & 33.5 & 36.03 & 41.9 & 45.43 & 37.05 & 10 \\
14 & PBL & 50.37 & 56.75 & 58 & 58.21 & 55.67 & 55.80 & 3 \\
15 & PuBL & 11 & 13.72 & 17.3 & 16.75 & 17.15 & 15.18 & 18 \\
16 & SBL & 49.71 & 55.82 & 68.95 & 66.79 & 68.98 & 62.05 & 2 \\
17 & SJIBL & 40.75 & 41.55 & 36.54 & 37.68 & 43.51 & 40.01 & 8 \\
18 & SIBL & 27.17 & 32.69 & 32.73 & 41.3 & 43.96 & 35.57 & 11 \\
19 & TBL & 27.43 & 28.02 & 37 & 37.02 & 31.97 & 32.29 & 12 \\
20 & UCBL & 20.12 & 23.77 & 30.99 & 41.3 & 42.11 & 31.66 & 13 \\
\hline
\end{tabular}

Source: Annual reports of the sample banks

\subsection{Relationship between HRD investment and bank productivity and profitability}

One of the hypotheses of the study is that there is no association between specific HRD indicators and deposit per employee (Productivity measure) and ROI (the Profitability measure). To test this hypothesis correlation matrix has been prepared as shown below:

Table 5: Relationship between HRD investment and bank productivity and profitability

\begin{tabular}{lccccccc}
\hline & $\mathrm{X}_{1}$ & $\mathrm{X}_{2}$ & $\mathrm{X}_{3}$ & $\mathrm{X}_{4}$ & $\mathrm{X}_{5}$ & $\mathrm{Y}_{1}$ & $\mathrm{Y}_{2}$ \\
\hline $\mathrm{X}_{1}$ & 1 & & & & & & \\
$\mathrm{X}_{2}$ & $.478^{* *}$ & 1 & & & & & \\
$\mathrm{X}_{3}$ & $.379^{* *}$ & $.398^{* *}$ & 1 & & & & \\
$\mathrm{X}_{4}$ & $.450^{* *}$ & $.486^{* *}$ & $.210^{*}$ & 1 & & \\
$\mathrm{X}_{5}$ & $.548^{* *}$ & $.570^{* *}$ & $.367^{* *}$ & $.506^{* *}$ & 1 & & \\
$\mathrm{Y}_{1}$ & .068 & $.215^{*}$ & .043 & .085 & .062 & 1 & \\
$\mathrm{Y}_{2}$ & .181 & .050 & .184 & $.218^{*}$ & .034 & .112 & 1 \\
\hline
\end{tabular}

** Correlation is significant at the 0.01 level (2-tailed).

* Correlation is significant at the 0.05 level (2-tailed).

Source: Compiled by the researchers using SPSS program 
The Table 5 reveals that the relationship between X2 (Bonus and Others) and Y1 (ROI) is positive and also statistically significant at the 1\% level. Again, the relationship between X4 (Training \& others) and Y2 (DPE) has also been positive and statistically significant at 1\% level. But the relationship between $\mathrm{X} 1$ and $\mathrm{Y} 1$ and $\mathrm{Y} 2$ respectively, $\mathrm{X} 2$ and $\mathrm{Y} 2, \mathrm{X} 3$ and $\mathrm{Y} 1$ and $\mathrm{Y} 2$ respectively, $\mathrm{X} 4$ and $\mathrm{Y} 1$ and $\mathrm{X} 5$ and $\mathrm{Y} 1$ and $\mathrm{Y} 2$ respectively have been positive but not statistically significant. Such positive relation between independent variables $\mathrm{X} 1, \mathrm{X} 2, \mathrm{X} 3, \mathrm{X} 4, \mathrm{X} 5$, and the dependent variable $\mathrm{Y} 1$ and $\mathrm{Y} 2$ respectively implies that the more investment in HRD indicators, the more the ROI and DPE and vice versa. From the analysis, therefore, it can be said that null hypothesis has been rejected implying thereby that investment in each indicator of HRD has a positive relationship with ROI and DPE of the selected banks.

\subsection{Impact of investment in HDR on Bank productivity and profitability}

In order to measure the impact of the specific indicators of HRD namely Salaries and Allowance (X1), Bonus and others (X2), Provident fund and Gratuity (X3), Training (X4), Staff Welfare (X5) herein known as independent variables and ROI (Y1) and DPE (Y2) known as dependent variables, the following two regression models have been developed. Model 1:

$\mathrm{Y} 1(\mathrm{ROI})=\beta 0+\beta 1 \mathrm{x} 1+\beta 2 \mathrm{x} 2+\beta 3 \mathrm{x} 3+\beta 4 \mathrm{x} 4+\beta 5 \mathrm{x} 5+\mathrm{e}$

Model 2:

$\mathrm{Y} 2(\mathrm{DPE})=\beta 0+\beta 1 \mathrm{x} 1+\beta 2 \mathrm{x} 2+\beta 3 \mathrm{x} 3+\beta 4 \mathrm{x} 4+\beta 5 \mathrm{x} 5+\mathrm{e}$

Where $\beta 0, \beta 1, \beta 2, \beta 3, \beta 4$ and $\beta 5$ are the regression co-efficient and $e$ is error term.

The results of model 1 are presented below:

Table 6: Regression (Y1=ROI)

Model Summary

\begin{tabular}{lcccr}
\hline Model & R & R Square & Adjusted R Square & Std. Error of the Estimate \\
\hline 1 & $.574^{\mathrm{a}}$ & .329 & .226 & 5.9224568 \\
\hline
\end{tabular}

a. Predictors: (Constant), X5, X3, X4, X2, X1 
HRD investment on financial performance 47

Table 6: to be continued ...

\begin{tabular}{llccccr}
\multicolumn{7}{c}{ ANOVA $^{\mathbf{b}}$} \\
\multicolumn{2}{c}{ Model } & Sum of Squares & Df & Mean Square & $\mathrm{f}$ & Sig. \\
\hline \multirow{2}{*}{1} & Regression & 267.792 & 5 & 53.558 & 1.527 & $.089^{\mathbf{a}}$ \\
& Residual & 3297.096 & 94 & 35.075 & & \\
& Total & 3564.888 & 99 & & & \\
\hline
\end{tabular}

a. Predictors: (Constant), X5, X3, X4, X2, X1

b. Dependent Variable: Y1

\section{Coefficients $^{\mathrm{a}}$}

\begin{tabular}{|c|c|c|c|c|c|c|}
\hline \multirow[b]{2}{*}{ Model } & & \multicolumn{2}{|c|}{$\begin{array}{c}\text { Unstandardized } \\
\text { Coefficients }\end{array}$} & \multirow{2}{*}{$\begin{array}{c}\begin{array}{c}\text { Standardized } \\
\text { Coefficients }\end{array} \\
\text { Beta }\end{array}$} & \multirow[b]{2}{*}{$\mathrm{t}$} & \multirow[b]{2}{*}{ Sig. } \\
\hline & & B & Std. Error & & & \\
\hline \multirow{6}{*}{1} & (Constant) & 10.467 & 1.007 & & 10.395 & .000 \\
\hline & $\mathrm{X} 1$ & .021 & .001 & .017 & 2.109 & .014 \\
\hline & $\mathrm{X} 2$ & .018 & .007 & .348 & 2.502 & .014 \\
\hline & $\mathrm{X} 3$ & .003 & .003 & .139 & 1.255 & .012 \\
\hline & X4 & .015 & .075 & .026 & 3.204 & .039 \\
\hline & X5 & .025 & .029 & .149 & 2.856 & .094 \\
\hline
\end{tabular}

a. Dependent Variable: Y1

Source: Compiled data using SPSS program

To test how well the model 1 fits the data and findings, coefficients of determination (R2) and ANOVA test are significant. It is seen in the above table that the value of $\mathrm{R} 2$ (Adjusted) is equal to 0.226 . This value of R2 signifies that investment in HRD can explain $22.6 \%$ of the observed variability in ROI. The variance is significant as indicated by F-value 1.527 at about $10 \%$ level of significance. Therefore, it can be concluded that regarding the return on investment (ROI) of the selected banks have been influenced by the investment in HRD indicators to the extent of $22.6 \%$ only.

The results of model 2 are presented below:

Table 7: Regression (Y2=DPE)

\begin{tabular}{lcccr}
\multicolumn{4}{c}{ Model Summary } \\
\hline Model & R & R Square & Adjusted R Square & Std. Error of the Estimate \\
\hline 2 & $.641^{\text {a }}$ & .411 & .371 & 15.37 \\
\hline
\end{tabular}

a. Predictors: (Constant), X5, X3, X4, X2, X1 
48 IIUC Studies, 14(2)

Table 7: to be continued...

\begin{tabular}{llccccr}
\multicolumn{7}{c}{ ANOVA $^{\mathbf{b}}$} \\
\multicolumn{2}{c}{ Model } & Sum of Squares & Df & Mean Square & $\mathrm{f}$ & Sig. \\
\hline \multirow{2}{*}{2} & Regression & 5992.018 & 5 & 1198.404 & 5.072 & $.000^{\mathrm{a}}$ \\
& Residual & 22211.454 & 94 & 236.292 & & \\
& Total & 28203.472 & 99 & & & \\
\hline
\end{tabular}

a. Predictors: (Constant), X5, X3, X4, X2, X1

b. Dependent Variable: Y2

Coefficients $^{\mathrm{a}}$

\begin{tabular}{ccccccr}
\hline \multirow{2}{*}{ Model } & \multicolumn{5}{c}{$\begin{array}{c}\text { Unstandardized } \\
\text { Coefficients }\end{array}$} & $\begin{array}{c}\text { Standardized } \\
\text { Coefficients }\end{array}$ \\
\cline { 3 - 5 } & & $\mathrm{B}$ & Std. Error & Beta & $\mathrm{t}$ & Sig. \\
\cline { 3 - 6 } 2 & (Constant) & 36.980 & 2.613 & & 14.150 & .000 \\
& $\mathrm{X} 1$ & .009 & .003 & .375 & 2.623 & .010 \\
& $\mathrm{X} 2$ & .031 & .019 & .213 & 1.661 & .010 \\
& $\mathrm{X} 3$ & .015 & .007 & .224 & 2.193 & .031 \\
& $\mathrm{X} 4$ & .582 & .196 & .351 & 2.973 & .004 \\
& $\mathrm{X} 5$ & .222 & .076 & .467 & 2.920 & .004 \\
\hline
\end{tabular}

a. Dependent Variable: Y2

Source: Compiled data using SPSS program

To test how well the model 2 fits the data and findings, coefficients of determination (R2) and ANOVA test are significant. It is seen in the above table that the value of R2 (Adjusted) is equal to 0.371 . This value of R2 signifies that investment in HRD can explain 37.1\% of the observed variability in DPE. The variance is highly significant as indicated by Fvalue 5.072 at about $1 \%$ level of significance. Therefore, it can be concluded that the investment in HRD indicators has influenced DPE of the selected banks to the extent of $37.1 \%$. From the analysis of the model1 and model-2, it can be said that null hypothesis has been rejected implying thereby that investment in HRD has a significant impact on ROI and DPE of the selected banks.

\section{Conclusion}

From the analyses of the study, it is seen that the major indicators of HRD investment, in order of importance are salaries and allowances, provident fund and gratuity, bonus and incentives, staff welfare and training, workshop, seminar, etc. Thus, it is seen that the lowest investment is made in the training and development of human resources 


\section{HRD investment on financial performance 49}

thereby neglecting this vital indicator of investment in HRD. The correlation matrix reveals that there is a positive relationship between each of the independent variables and dependent variables. Again, the regression models indicate that the investment in HRD has a positive impact on both the DPE and ROI of the sample banks. The significant contribution of this paper is to persuade HR managers and the top management of the banks to take serious attention on the higher investment in HRD indicators especially in training and development and employee welfare to make the banking sectors effective and dynamic for sustainable economic growth. Further studies may be conducted in the context of manufacturing and other service sector enterprises with larger sample size. Case studies, focus groups, and longitudinal studies may also be undertaken in this vital issue of HRM.

\section{References}

Al-Ghazawi, M. (2012). The impact of investments in human resource activities on the effectiveness of investment in human capital: The case of commercial banks in Jordan. International Journal of Business and Social Science, 3(18), 253261.

Armenta, M. W. (2007). The financial sector and economic development: Banking on human capital. Journal of Public and International Affairs, 18, 188203.

Arthur, J. B. (1994). Effects of human resource systems on manufacturing performance and turnover. Academy of Management Journal, 37(3), 670-687.

Aswathappa, K. (2008). Human Resource Management: Text and Cases. Delhi: Tata McGraw-Hill Publishing Company Limited.

Baniya, L. B. (2004). Human resource development practice in Nepalese business organizations: A case study of manufacturing enterprises in POKHARA. The Journal of Nepalese Business Studies, 1(1), 88-98.

Bartell, A. P. (2004). Human resource management and organizational performance: Evidence from retail banking. Industrial and Labour Relations Review, 57(2), 181-203.

Becker, B. E., \& Huselid, M. A. (1992). Direct Estimates of SDy and the Implications for Utility Analysis. Journal of Applied Psychology, 77, 227-233. 


\section{IIUC Studies, 14(2)}

Becker, B., \& Gerhart, B. (1996). The Impact of human resource management on organizational performance: Progress and prospects, The Academy of Management Journal, 39(4), 779-801.

Benjamin, A. (2011). An assessment of human resource development climate in Rwanda private sector organisations. International Bulletin of Business Administration, 12, 56-68.

Bhuiyan, M. Z. H., Islam, M. M., \& Rahman, M. A. (2013). Impact of productivity on profitability of some selected commercial banks (PCBs) in Bangladesh. Journal of Banking and Financial Services, 14(1\&2), 83-102.

Billah, M. M., \& Islam, S. (2009). Human resource management practices and organizational commitment; a survey on private commercial banks in Bangladesh. Southeast University Journal of Business Studies, 1, 153-166.

Billah, M. M., Prince, S. A., \& Islam, S. (2009). Human resource management practices and employee turnover; A study on private commercial banks in Bangladesh. Journal of Business and Technology, 4(1), 63-82.

Bohlander, G., \& Snell, S. (2004). Implementing compensation and security. Managing Human Resources, 439-442.

Borman, W. C. (1991). Job behavior, performance, and effectiveness. In M. D. Dunnette, \& L. M. Hough (Eds.), Handbook of industrial and organizational psychology (2d ed.), 2, 271-326. Palo Alto, CA: Consulting Psychologists Press.

Bradley, S., Petrescu, A., \& Simmons, R. (2004). The impacts of human resource management practices and pay inequality on workers' job satisfaction. Paper presented at the Western Economic Association 79th Annual Conference V ancouver.

Cappelli, P., \& Anne, C. H. (1996). Distinctive human resources are firms' core competencies. Organizational dynamics, 24, 7-22.

Delaney, J. T., \& Huselid, M. A. (1996). The Impact of Human Resource Management Practices on Perceptions of Organizational Performance. The Academy of Management Journal, 39(4), 449-469.

Ebiringa, O. T., \& Okorafor, G. F. (2010), Effects of human capital development on the performance of small and medium scaled enterprises in the South-Eastern region of Nigeria. Journal of Sustainable Development in Africa, 12(8), 49-58.

Gerhart, B., \& Milkovich, G. T. (1992). Employee compensation: Research and practice. In M. D. Dunnette, \& L. M. Hough (Ed.), Handbook of industrial and organizational psychology, 3, 481-569. Palo Alto, CA: Consulting Psychologists Press.

Gidado, M. A., Kusairi, S., \& Muhamad. S. (2014). Investing in human resource development: Empirical evidence from banking institutions of Malaysia and Nigeria. Journal of Economics and Sustainable Development, 5(12), 123-132. 


\section{HRD investment on financial performance 51}

Grossman, R. J. (2000). Measuring up: Appropriate metrics help HR prove its worth. HR Magazine, 45, 28-35.

Guest, D. E. (1997). Human resource management and performance: A review and research agenda. The International Journal of Human Resource Management, 8(3), 263-276. DOI:10.1080/095851997341630

Guest, D. E. (2011). Human resource management and performance: Still searching for some answers. Human Resource Management Journal, 21(1), 3-13.

Harel, G. H., \& Tzafrir, S. S. (2004). The effect of human resource management practices on the perceptions of organizational and market performance of the firm. Human Resource Management, 38(3), 185-200.

Hoque, M. J. (1994). Human resource development and organizational effectiveness. In R. B. Talukder (Ed.), Management of Change in South Asia (pp. 433-451). Dhaka: UPL.

Hsu, I. C., Lin, C. Y. Y., Lawler, J. J., \& Wu, S. H. (2007). Toward a model of organizational human capital development: Preliminary evidence from Taiwan. Asia Pacific Business Review, 13, 251-275.

Huselid, M. A. (1993). Essays on buman resource management practices, turnover, productivity, and firm performance. Unpublished $\mathrm{PhD}$ Dissertation: State University: Buffalo, New York.

Huselid, M. A. (1995). The impact of human resource management practices on turnover, productivity, and corporate financial performance. Academy of Management Journal, 38, 635-672.

Ivancevich, J. A. (2003). Human Resource Management (9th ed.). New York: McGrawHill.

Jones, G. R., \& Wright, P. M. (1992). An economic approach to conceptualizing the utility of human resource management practices. In K. Rowland, \& G. Ferris (Eds.), Research in Personnel and Human Resources Management, 10, 271 299. Greenwich, CT: JAI Press.

Khan, M. A., \& Ali, A. J. (2014). The role of training in reducing poverty: The case of the ultra-poor in Bangladesh. International Journal of Training and Development, 18(4), 271-281. DOI: 10.1111/ijtd.12041

Khan, M. A., \& Ali, A. J. (2015). Do non-governmental organisations' socioeconomic and training programmes improve disaster prevention capacity of their beneficiaries? International Social Work, 58(3), 401-420. DOI: 10.1177/0020872815570074

Lado, A. A., \& Wilson, M. C. (1994). Human resource systems and sustained competitive advantage: A competency-based perspective. Academy of Management Review, 19(4), 699-727. 


\section{IIUC Studies, 14(2)}

Lee, F-H., \& Lee, F-Z. (2007, November). The relationships between HRM practices, leadership style, competitive strategy and business performance in Taiwanese steel industry. In Proceedings of the 13th Asia Pacific Management Conference, Melbourne, Australia (pp. 953-971).

Lepak, D., \& Snell, S. (1999). The human resource architecture: Toward a theory of human capital allocation and development. Academy of Management Review, 24(1), 31-48.

Lepak, D., \& Snell, S. (2002). Examining the human resource architecture: The relationships among human capital, employment and resource configurations. Journal of Management, 28(4), 517-543.

Liao, S. Y. (2005). Business strategy and performance: The role of human resource management control. Business Strategy performance, 34(3), 294-309.

Olayemi, S. O. (2012). Human capital investment and industrial productivity in Nigeria. International Journal of Humanities and Social Science, 2(16), 298-307.

Qureshi, M. T., Akbar, A., Khan, A. M., Sheikh, A. R, \& Hijazi, T. S. (2010). Do human resource management practices have an impact on financial performance of banks? African Journal of Business Management, 4(7), 1281-1288.

Randall, D. J., \& Ferry, S. F. (1992). 4 Catecholamines. In Fish physiology (Vol. 12, pp. 255-300). Academic Press.

Rawashdeh, A. M., \& Al-Adwan, I. K. (2012). The impact of human resource management practices on corporate performance: Empirical study in Jordanian commercial banks. African Journal of Business Management, 6(41), 10591-10595. DOI: 10.5897/AJBM12.1169

Russell, J. S., Terborg, J. R., \& Powers, M. L. (1985). Organizational performances and organizational level training and support. Personnel Psychology, 38, 849-863.

Selvarajan, T. T., Ramamoorthy, N., Flood, P. C., Guthrie, J. P., MacCurtain, S., \& Liu, W. (2007). The role of human capital philosophy in promoting firm innovativeness and performance: Test of a causal model. International Journal of Human Resource Management, 18(8), 1456-1470.

Singh, K. (2004). Impact of HR practices on perceived firm performance in India. Asia Pacific Journal of Human Resources, 42(3), 301-317.

Stavrou-Costea, E. (2005). The challenges of human resource management towards organizational effectiveness. Journal of European Industrial Training, 29(2), 112-134.

Swanson, R. A. (1995). Human resource development: Performance is the key. Human Resource Development Quarterly, 6(2), 207-213.

Sweetland, S. R. (1996). Human capital theory: Foundations of a field of inquiry. Review of Educational Research, 66(3), 341-359. 


\section{HRD investment on financial performance 53}

Terpstra, D. E., \& Rozell, E. J. (1993). The relationship of staffing practices to organizational level measures of performance. Personnel Psychology, 46(1), 2748.

Thang, N. N., \& Buyens, D. (2008). What we know about relationship between training and firm performance: $A$ review of literature. Paper presented at the 7th International Conference on Ethics and Quality of Work-Life for Sustainable Development, Bangkok, Thailand.

Tzafrir, S. S. (2006). A universalistic perspective for explaining the relationship between HRM practices and firm performance at different points in time. Journal of Managerial Psychology, 21(2), 109-130.

Wan, D., Ong, C. H., \& Kok, V. (2002). Strategic human resource management and organizational performance in Singapore. Compensation and Benefits Review, 34(4), 33-42.

Weston, J. F., \& Brigham. F. E. (1969). Managerial finance. New York: Holtrenehart and Winston.

Wright, P. M., \& McMahan, G. C. (1992). Theoretical perspectives for strategic human resource management. Journal of Management, 18(2), 295-320.

Zaini A., Nilufar, A., \& Syed, S. A. (2009). The effect of human resource management practices on business performance among private companies in Malaysia. International Journal of Business and Management, 4(6), 65-72.

\section{Corresponding author}

Mohammad Zahid Hossain Bhuiyan can be contacted at: zahidsita@gmail.com 
54 IIUC Studies, 14(2)

\section{Appendix 1}

\section{Name of the selected banks}

1. $\mathrm{ABBL}=\mathrm{AB}$ Bank Limited

2. $\mathrm{BAL}=$ Bank Asia Limited

3. $B B L=B R A C$ Bank Limited

4. $\mathrm{CBL}=$ City Bank Limited

5. $\quad \mathrm{DBL}=$ Dhaka Bank Limited

6. $\mathrm{DBBL}=$ Dutch-Bangla Bank Limited

7. $\mathrm{EBL}=$ Eastern Bank Limited

8. FSIBL=First Security Islami Bank Limited

9. $\quad \mathrm{IBBL}=$ Islami Bank Bangladesh Limited

10. $\mathrm{ICB}=\mathrm{ICB}$ Islami Bank Limited

11. IFIC $=$ International Finance Investment and Commerce Bank Limited (IFIC)

12. $\mathrm{MTBL}=$ Mutual Trust Bank Limited

13. NCCBL $=$ National Credit \& Commerce Bank Limited

14. $\mathrm{PBL}=$ Prime Bank Limited

15. $\mathrm{PuBL}=$ Pubali Bank Limited

16. $\mathrm{SBL}=$ Southeast Bank Limited

17. SJIBL $=$ Shahjalal Islami Bank Limited

18. SIBL $=$ Social Islami Bank Limited

19. $\mathrm{TBL}=$ Trust Bank Limited

20. $\mathrm{UCBL}=$ United Commercial Bank Limited 